\title{
KETIKA KESAKRALAN SITUS PURBAKALA MULAI PUDAR (Studi Antropologi Budaya Terhadap Keberadaan Arca Antromorfis Bagi Masyarakat Pakpak Desa Mahala Kecamatan Tinada Kabupaten Pakpak Bharat Sumatera Utara)
}

Lasmayanti Siketang

Prodi Antropologi Fisip Universitas Malikussaleh

\begin{abstract}
Abstrak
Artikel ini melihat Kesakralan Situs Purbakala yang Mulai Pudar, Studi Antropologi Budaya Terhadap Keberadaan Mejan di Desa Mahala Kecamatan Tinada Kabupaten Pakpak Bharat Sumatera Utara. Mejan adalah istilah yang menyatakan patung batu dalam bahasa Pakpak yang berbentuk manusia sedang menunggang gajah atau kuda pada umumnya digunakan sebagai objek berhala dan merupakan simbol kepahlawanan dan benteng pertahanan bagi masyarakat Pakpak. Menggunakan metode kualitatif dengan pendekatan analisis deskriptif, data yang digunakan seperti, observasi, wawancara. Observasi dilakukan untuk melihat situs purbakala dan aktivitas masyarakat di Desa Mahala. Tehnik analisis data dalam penelitian ini adalah teknik analisis interaktif dengan tahapan dimulai dari pemilihan masalah, pengumpulan data, menganalisis data, dan penarikan kesimpulan. Hasil penelitian menunjukkaan bahwa ada beberapa hal yang menyebabakan terjadinya pergeseran pemahaman masyarakat terhadap situs purbakala seperti mejan saat ini. Pertama, masyarakat telah menyakini agama-agama besar yang telah diakui oleh Negara sehingga kepercayaan terhadap mejan hilang. Kedua, masyarakat telah memahami peraturan hokum yang berlaku di masyarakat. Ketiga, memudarnya pemahaman masyarakat terhadap mejan terkiks oleh kemajuan zaman yang semakin tahun semakin modern. Seiring berjalannya waktu dan kemajuan zaman fungsi mejan mulai berubah, mejan hanya menjadi benda-benda peninggalan yang bersejarah bagi masyarakat.
\end{abstract}

Kata kunci: situs, kesakralan, antopologi budaya, sumatera utara

\section{Pendahuluan}

Dahulu masyarakat Pakpak menganggap Mejan merupakan salah satu simbol kebanggaan dan kemansyuran suku Pakpak yang diukir oleh para nenek moyang terdahulu sekitar ratusan tahun silam. Mejan dapat berbentuk macam-macam seperti, manusia menunggang gajah, manusia 
menunggang kuda, beraspati (kelang), anjing dan bentuk lainnya. Fungsi mejan dijadikan sebagai benteng pertahanan terhadap musuh yang akan masuk kedalam suatu daerah atau kampung. Mejan juga akan bersuara apabila suatu kampung akan mengalami peristiwa tertentu. Lain halnya dengan pandangan masyarakat sekarang ini mengenai mejan. Sekarang mejan dianggap sebagai benda atau artefak peninggalan sejarah purbakala dan warisan budaya leluhur nenek moyang suku Pakpak yang merupakan ciri khas suku Pakpak, khususnya Pakpak Bharat. Bagi masyarakat Pakpak, mejan merupakan patung-patung yang menyimpan nilai sejarah kebudayaan mereka yang dulunya merupakan sarat akan kandungan unsur mistik (alam gaib).

Secara Etimologis, Pakpak artinya puncak gunung. Orang Pakpak disebut orang pegunungan karena sebagian besar hidup dan bertempat tinggal di pegunungan. Ada beberapa pendapat mengenai asal-usul orang Pakpak. Namun pendapat yang diterima masyarakat adalah orang Pakpak datang bersamaan dengan kedatangan gelombang penduduk dari Indo Cina ke nusantara yang diperkirakan terjadi 4000 sebelum masehi. Pada masa pra-kolonial, tanah Pakpak telah menjadi wilayah perdagangan. Pada masa itu banyak orang Pakpak yang menjadi pedagang, dan salah satu tempat aktivitas ekonominya adalah Salak (Berutu, 2013: 5). Sementara itu dari hasil penelitian yang dilakukan menunjukkan beberapa variasi. Pertama dikatakan bahwa orang Pakpak berasal dari India yakni pedagang-pedagang India yang menetap di Barus dan selanjutnya masuk kepedalaman dan keturunannya berkembang menjadi orang Pakpak. Versi lain menyatakan orang Pakpak berasal dari etnis batak Toba dan yang lain lagi menyatakan orang Pakpak sudah ada sejak dahulu.

Mana yang benar menjadi relatif, karena kurang didukung oleh faktafakta yang objektif. Alasan dari India misalnya hanya didasarkan pada adanya kebiasaan tradisional Pakpak dalam pembakaran tulang-belulang nenek moyang dan nama-nama merga (marga dalam bahasa Pakpak) yang diduga merupakan nama-nama adopsi dari India seperti marga Maha dan Lingga serta Barus sebagai daerah pantai dan pusat perdagangan berbatasan langsung dengan tanoh Pakpak. Alasan Pakpak berasal dari Batak Toba hanya karena adanya kesamaan struktur sosial dan kemiripan nama-nama marga. Sedangkan alasan ketiga menyatakan dari dahulu kala sudah ada orang Pakpak hanya didasarkan pada folklor dimana diceritakan adanya tiga zaman manusia di tanoh Pakpak yakni : zaman tuara , zaman si aji , dan zaman manusia (homo sapiens) (Wahyudhi, 2002: 6).

Soedewo (2009: 60) Pengaruh peradaban luar pertama yang menyentuh kebudayaan suku Pakpak adalah peradaban yang berasal dari 
India berupa sistem keagamaan, yakni agama Hindu (Skripsi Saut Banurea, 2014 :3). Sejumlah unsur budaya Hindu (India) ini telah memperkaya kebudayaan Pakpak sebagimana jejak-jejak kebudayaan Hindu sampai sekarang masih tampak jelas di Kabupaten Pakpak Bharat seperti mejan. Keberadaan peninggalan situs purbakala (mejan) di wilayah kabupaten ini merupakan bukti perjalanan sejarah dan budaya di daerah ini.

Meliala membahas mengenai masyarakat Jepang yang mempertahankan dan memelihara tradisi kebudayaan leluhur dari generasi ke generasi. membahas mengenai negara Jepang yang sudah banyak mengalami proses modernisasi dalam berbagai bidang sehingga menjadikannya sebagai negara yang maju. Secara langsung, daerah Okinawa juga tersentuh oleh proses modernisasi tersebut. Namun uniknya masyarakat Okinawa masih mempertahankan dan mempercayai mitosmitos tentang benda tertentu yang memiliki kekuatan supranatural dapat melindungi. Patung shisa memiliki nilai kearifan lokal. Nilai-nilai ini ditaati dan menjadi pelindung. Sehingga nilai-nilai kearifan lokal yang terdapat dalam kepercayaan terhadap patung shisa ikut memberikan pengaruh dalam terciptanya kehidupan masyarakat yang aman dan teratur. Relevansi penelitian yang dilakukan oleh Mike Meliala (2015) adalah samasama mengkaji mengenai pandangan masyarakat terhadap patung pelindung kampung. Dan sama-sama meneliti mengenai makna patung terhadap masyarakat. Namun, terdapat perbedaan antara penelitian Mike Meliala dan peneliti dimana peneliti mengkaji mengenai interpretasi masyarakat terhadap mejan situs purbakala sementara Mike Meliala mengkaji masyarakat Okinawa yang masih mempertahankan dan mempercayai mitos-mitos tentang benda tertentu yang memiliki kekuatan supranatural walaupun Jepang sudah banyak mengalami proses modernisasi dalam berbagai bidang.

Astuti Penulis memilih judul ini dikarenakan tertarik akan pembahasannya yang unik, dan terdapat perbedaan diantara pandangan masyarakat Jepang dan Indonesia. Karena beberapa agama di Indonesia percaya bahwa bayi dan janin yang meninggal akan masuk ke surga karena dianggap masih suci. Sedangkan masyarakat di Jepang menganggap sebaliknya, bahwa bayi dan janin yang meninggal akan masuk neraka.Penelitian ini menunjukkan bahwa eksistensi kepercayaan masyarakat Jepang terhadap patung ojizo sangat tinggi. Hal ini disebabkan karena patung ojizo dipercayai sebagai pelindung arwah bayi. Disini penulis menggunakan pendekatan penelitian sosiologis, karena pembahasan dalam pendekatan ini mencakup golongan sosial yang berperan, jenis hubungan sosial, konflik berdasarkan kepentingan, 
pelapisan sosial, peranan dan status sosial dan sebagainya. Penulis menggunakan pendekatan ini adalah untuk mengetahui latar belakang dan pengaruh patung Ojizo di Jepang. Relevansi penelitian yang dilakukan oleh Fuji Astuti (2014) adalah sama-sama mengkaji tentang fungsi patung kepercayaan masyarakat namun berbeda pada jenis patung yang diteliti. Peneliti melakukan penelitian pada interpretasi masyarakat terhadap mejan sedangkan Fuji Astuti meneliti tentang fungsi patung Ojizo sebagai pelindung arwah bayi. Penelitian ini sama-sama menggunakan metode penelitian deskriptif, yaitu penelitian yang menggambarkan peristiwa atau gejala apa adanya, dengan cara penyusunan yaitu mengumpulkan, menyusun, mengklasifikasikan, mengkaji dan menginterpretasikan data.

Rahman, menjelasan tentang kepercayaan lokal Masyarakat Asmat terhadap Patung Mbis yang sering dilakukan dalam bentuk suatu upacara ritual. Dalam tulisannya penulis membahas permasalahan faktor-faktor apa yang mempengaruhi munculnya ide untuk melaksanakan pesta mbis pada masyarakat Asmat, serta fungsi-fungsi apa yang terkandung dalam upacara mbis. Sejauhmana upacara atau pesta mbis itu berpengaruh terhadap kehidupan masyarakat Asmat. Dalam hal ini penulis menggunakan pendekatan teori strukturalisme A. R. Radcliffe-Brown sebagai kerangka acuan dalam mendeskripsikan upacara patung mbis. Hasil pengkajian ini mengungkapkan bahwa upacara patung Mbis sangat mempengaruhi perilaku kehidupan masyarakat Asmat walaupun berbenturan dengan nilai-nilai religus agama, akan tetapi upacara patung Mbis sampai saat ini masih dilakukan oleh masyarakat Asmat sebagai bentuk pelestarian budaya lokal di Asmat.

\section{Metode Penelitian}

Penelitian ini menggunakan metode kualitatif dan menggunakan pendekatan deskriptif untuk melihat perubahan yang terjadi di masyarakat Desa Mahala mengenai kesakralan situs purbakala seperti mejan. Proses pengumpulan data melalui wawancara dengan masyarakat desa mahala. obsevasi dilakukan dalam megamati perubahan pandangan penduduk dahulu dan masyarakat saat ini. Data dalam arttikel merupakan pengembangan lebih laanjut atas penelitian yang penulis lakukan padata tahun 2017. Pengumpulan data tambahan dilakukan selama april-juni, 2017. 


\section{Hasil Dan Pembahasan}

\section{Gambaran Lokasi Arca Antromorfis}

Dalam penelitian ini penulis melakukan penelitian di Kecamatan Tinada Kabupaten Pakpak Bharat khususnya di Desa Mahala. karena berdasarkan observasi awal (hasil pengamatan di lapangan) di desa tersebut terdapat patung peninggalan sejarah yang oleh masyarakatnya disebut dengan mejan. Dalam bahasa latin mejan disebut juga dengan Arca Antromorfis. Mahala adalah salah satu wilayah yang berada jauh dari titik pusat kota Kabupaten Pakpak Bharat. Secara administratif Desa Mahala terletak di daerah pedalaman Kabupaten Pakpak Bharat. Penduduk yang mendiami Desa Mahala ini mayoritas suku Pakpak yaitu Pakpak Simsim (Suak Simsim) seperti Marga Solin, Boang Menalu, Bancin, Berutu,Tumangger, Manik, dan Cibro. Akan tetapi marga dominan adalah Marga Solin di setiap kuta dan sebagian kecil suku lain yaitu Batak Toba seperti marga Simbolon, Sianturi, Dan Silalah. Suku Karo seperti Marga Sitepu, dan suku Jawa. Suku Batak Toba. Desa Mahala ini terbilang masih sagat kental dengan nilai-nilai religious dan adat istiadat. Karena suku Pakpak diikat oleh struktur sosial yang dalam istilah setempat dengan sulang silima. Sulang silima

\section{Pemahaman Masyarakat Desa Mahala Dalam Memahami Keberadaan Mejan (Arca Antromorfis) Sebagai Situs Purbakala}

Situs memiliki berbagai pengertian yang berbeda karena selain dalam dunia computer dan internet, didalam dunia sejarah juga terdapat istilah situs. Bila dalam dunia komputer dan internet situs merupakan website, sebuah alamat yang bisa kita kunjungi dan berisi informasi tertentu tentang pemilik website, maka kata situs dalam dunia sejarah berhubungan dengan tempat atau area atau wilayah. Menurut William Haviland mengatakan bahwa "tempat-tempat dimana ditemukan peninggalan-peninggalan arkeologi di kediaman makhluk manusia pada zaman dahulu dikenal dengan nama situs. Situs biasanya ditentukan berdasarkan survey suatu daerah". Lebih lanjut William Haviland juga mengatakan bahwa "artefak/artefak adalah sisa-sisa alat bekas suatu kebudayaan zaman prehistori yang digali dari dalam lapisan bumi. Artefak ialah objek yang dibentuk atau diubah oleh manusia".

Berdasarkan penjelasan di atas, dapat disimpulkan bahwa situs diketahui karena adanya artefak. Ahli arkeologi mempelajari peninggalanpeninggalan yang berupa benda untuk menggambarkan dan menerangkan perilaku manusia. Jadi situs sejarah adalah tempat dimana terdapat informasi tentang peninggalan-peninggalan bersejarah. Salah satunya adalah mejan (arca antromorfis). 


\section{Menurut Masyarakat Pakpak Tradisional}

Fungsi adalah tugas sosial suatu kegiatan yang harus dilaksanakan dengan tingkat ketepatan tertentu apabila ada pengelompokan sosial dan mempertahankan keanggotaan kelompoknya (Fedyani, 2005 :159). Fungsi adalah suatu yang berkenaan dengan kegunaan. Pengertian tersebut cukup jelas bahwa fungsi adalah sesuatu yang memiliki daya guna. Felmand Elmund Burke menjelaskan tentang teori fungsi seni. Pada dasarnya fungsi seni dapat dibagi kedalam empat macam antara lain : fungsi sosial, fungsi pribadi, fungsi fisik dan fungsi religi. Dalam kaitannya dengan hal ini bahwa mejan (patung) cenderung pada fungsi sosial, fungsi religi dan fungsi fisik.

Fungsi sosial dalam tiga tingkat abstraksi (Kaberry, $1957: 82$ ) yaitu :

1. Fungsi sosial dari suatu adat, pranata sosial atau unsur kebudayaan pada tingkat abstraksi pertama mengenai pengaruh atau efeknya terhadap adat. Tingkah laku manusia atau pranata sosial yang lain dalam masyarakat.

2. Fungsi sosial dari suatu adat, pranata sosial atau unsure kebudayaan pada tingkat abstarksi kedua mengenai pengaruh atau efeknya terhadap kebutuhan suatu adat atau pranata lain unruk mencapai maksutnya, seperti yang dikonsepsikan oleh warga masyarakat yang bersangkutan

3. Fungsi sosial dari suatu adat atau pranata sosial pada tingkat abstraksi ketiga mengenai pengaruh atau efeknya terhadap kebutuhan mutlak untuk berlangsungnya secara terintegrasi dari suatu sistem sosial yang tertentu (Koentjaraningrat, 1987: 167).

Fungsi Patung (mejan) Pada zaman dahulu mejan di fungsikan sebagai lambang kemansyuran atau kebesaran seorang raja. Karena mejan merupakan harta dan kebanggaan bagi yang meilikinya. Sehingga apabila di suatu desa terdapat beberapa mejan berarti raja dalam desa tersebut dulunya sangat kaya, sehingga mampu membuat mejan. Karena dalam proses pembuatan mejan memerlukan biaya yang sangat banyak dalam kurun waktu yang lama.

Mejan juga berfungsi sebagai benteng pertahanan. Karena di dalam mejan tersebut memiliki nangguru, sehingga mejan memili kekuatan untuk menangkal bala dan serangan dari musuh. Apabila seseorang mememilki niat buruk pada desa mejan dapat menyebabkan orang tersebut tersesat. 
Selain berfungsi sebagai benteng pertahanan, mejan juga dapat berfungsi sebagai penagkal dan pemberi tanda dengan bersuara ketika akan terjadi sesuatu, misalnya seperti henda gempa bumi.

Mejan sebagai simbol kepahlawanan, karena mejan merupakan salah satu wujud penghargaaan kepada seseorang yang dianggap berpengaruh atau berjasa kepada masyarakat. Mejan juga diyakini sebagai tanda hak ulayat atas tanah seorang raja. Biasanya mejan diletakkan di tempat yang menurut masyarakat dahulu suci. Mejan juga berperan sebagai tanda batas wilayah. Pada dasarnya mejan merupakan milik satu marga oleh sebab itu raja yang ada di desa adalah raja marga. Mejan juga berfungsi sebagai objek penyembahan dahulu kala. Pada zaman sekarang mejan sudah dijadikan sebagai benda atau artefak peninggalan sejarah purbakala dan warisan budaya lelulur nenek moyang suku Pakpak. Seperti yang dikatakan oleh ibuk Tenti Solin (76) pada tanggal 24 April 2017, mejan berfungsi sebagai simbol kejayaan marga yang memilikinya. "Orang di sini biasa menyebut mejan dengan sebutan lebuh paturdun pertaki kuta nangka., Ini adalah mejan tertua di desa ini, dibandingkan dengan mejan penghulubalang didekat perbatas desa sebelah barat ujar ibu tenti".

Lapisan lumut dan warna permukaan patung-patung yang menghitam itu memperkuat penjelasan Tenti Solin. Sebagai pendatang juga merasakan panorama purba dan nuansa aroma mistis yang semuanya makin menegaskan usia batuan yang sudah sangat tua. Sayang sekali, sebagian besar batu-batu ukiran itu sudah tidak utuh lagi. Misalnya, kepala patung manusia yang sedang menunggang gajah telah lenyap entah ke mana. Untuk hal ini, ibuk Tenti lagi-lagi punya penjelasan.

"Dulu patung-patung ini sangat lengkap dan bagus. Tapi sekarang jadi berantakan begini. Dari cerita-cerita orang tua dahulu, harimau yang buat kepala-kepala mejan ini rusak. Dulu fungsi mejan dijadikan sebagai benteng pertahanan terhadap musuh yang akan masuk ke suatu daerah atau kampung. Konon pada zaman dahulu, mejan dapat bersuara apabila musuh datang memasuki kampung. Mejan juga bersuara apabila suatu kampung akan mengalami peristiwa tertentu. Untuk itu, membuat mejan adalah sebuah pekerjaan besar, dan hanya orang yang sangat kaya dari suatu klan yang bisa melakukannya. Selain membutuhkan dana besar, proses membuat mejan juga membutuhkan waktu yang sangat lama, dan syarat-syarat spritual yang harus dipenuhi. Satu mejan, dibutuhkan waktu berbulan-bulan. "Misalnya saya ingin membuat patung ayah saya. Saya harus meletakkannya di pinggir jalan dengan pahatan dasar. Lalu penyempurnaannya dilakukan melalui pendapat orang-orang yang mengenal ayah saya yang kebetulan 
melintas di jalan. Ada yang mungkin mengatakan hidungnya kurang mancung, matanya harus menyimpan amarah, dan sebagainya. Sehingga dari hari demi hari, mejan itu akan mencapai kesempurnaan bentuk sesuai anggapan umum masyarakat terhadap profil ayah saya".

Fungsi Mejan Menurut Masyarakat Pakpak saat ini

Seiring dengan masuknya agama, fungsi mejan sekarang hanyalah menjadi benda-benda bersejarah yang kehilangan "kesaktian". Meskipun tidak fungsional dalam kehidupan masyarakat setempat, tapi justru sekaranglah minat terhadap mejan terasa lebih tinggi. Sepeti informan Jannes Solin (33) Tahun pada tanggal 25 april 2017:

"Kalau dulu tak pernah ada kasus kehilangan patung, kini banyak mejan ditemukan tanpa punya kepala, hilang dicuri oleh orang-orang yang tidak bertanggungjawab. Bagi kalangan tertentu (kalangan mistis), mereka meyakini bagian kepala patung mejan masih dihuni oleh nangguru. Dan perlu ritual untuk memanggil nanggurunya kembali, yang fungsinya untuk menjaga rumah dan menjaga ladang ataupun fungsi yang lebih besar. Baru-baru ini cawan mejan ini hampir dicuri oleh orang yang tidak bertanggung jawab dari luar daerah Kabupaten Pakpak Bharat. Tapi pada hal ini cawan itu dapat diselamatkan karena orang yang mencurinya dalam perjalanan meninggal dunia, dan orang yang mengangkat jenajahnya menemukan cawan yang diambilnya dan dikembalikan kembali ke tempatnya semula. .Masih ada kasus-kasus lain yang diduga berkaitan dengan perdagangan gelap barang bersejarah yang bisa jadi sindikatnya terhubung secara internasional. Mejan yang rata-rata hilang adalah mejan yang masih utuh atau masih ada kepalanya".

Menurut hasil wawancara peneliti dengan beberapa masyarakat di Desa Mahala bahwa, masyarakat lebih banyak berpendapat cara memahami keberadaan situs purbakala seperti mejan dengan mengetahui fungsi mejan walaupun pendapat masyarakat saat ini fungsi mejan hanyalah sebagai peninggalan sejarah semata.

Kemudian ada juga informan mengatakan bahwa untuk memahami keberadaan situs purbakala dengan melihat langsung mejan tersebut. Seperti yang dikatakan oleh Kardi Manik (28) Tahun pada tanggal 28 April 2017:

"cara saya memahami keberadaan mejan tersebut yaitu dengan cara saya melihat mejan itu sendiri agar saya lebih yakin bahwa mejan itu memang ada, tidak hanya cerita belaka. Setelah saya melihat langsung, 
saya juga sama seperti kamu, saya akan betanya mengenai mejan itu pada orang yang memiliki mejan tersebut".

Banyak masyarakat yang menganggap mejan itu hanyalah mitos belaka, apabila tidak melihat langsung objeknya. Karena lokasi ditempatkannya mejan ini berada jauh dari permukiman penduduk. Ada yang meletakkannya di tengah hutan belantara, seperti mejan yang ada di desa mahala ini. Sehingga ada beberapa masyarakat tidak pernah melihat situs purbakala ini, disebabkan oleh jarak tempuh yang memerlukan tenaga dan waktu yang berjam-jam untuk melihatnya.

Ada banyak infoman yang ditemui penulis, dengan pemahaman dan pendapat masing-masing mengenai keberadaan situs purbakala. Akan tetapi pendapat masyarakat lebih dominan kepada fungsi mejan sebagai situs purbakala sebagai cara mereka memahami keberadaan situs purbalaka. Ada juga informan bependapat dengan melihat objek masyarakat akan lebih memahami keberadan situs tersebut bukan hanya mitos yang didapat dari cerita-cerita rakyat.

\section{Melalui Cerita Turun Temurun}

Untuk memahami berbagai situs purbakala yang ada di berbagai daerah dilihat dari beberapa sudut pandang yang berbeda-beda. Khususnya bagi masyarakat Pakpak di Desa Mahala. Dari beberapa informan pendukung yang peneliti temui di lapangan, menjelaskan bahwasanya mereka memahami situs purbakala seperti mejan ini, dari ceritera orang-orang tua maupun yang dituakan di kuta tersebut. Ceritera mejan ini memang sering sekali terdengar apabila menyangkut tentang sejarah kuta. Para orang tua, maupun keturunan pertaki marga solin tidak pernah bosan menceritakan mengenai mejan tersebut, sehingga tidak jarang masyarakat yang ada di Desa Mahala tidak mengetahui keberadaan mejan tersebut.

Walaupun saat ini, kepercayaan terhadap mejan sudah mulai pudar akan tetapi masyarakat mengakui bahwa keberadaan mejan ini tidak akan pernah terlupakan, karena mejan ini merupakan sejarah dan harta pusaka bagi marga yang memilikinya. Tidak jarang pula, ada beberapa masyarakat yang tidak pernah sama sekali melihat bagaimana bentuk dan kondisi mejan yang ada di Mahala, akan tetapi karena sering mendengar ceritera dari para orang tua, mereka mengerti mengenai mejan tersebut. Sehingga dapat disimpulkan dari beberapa penjelasan yang dipaparkan oleh beberapa informan yang di temui di lapangan bahwa, untuk mengetahui situs purbakala seperi mejan ini, tidak harus melihat dengan langsung objeknya, akan tetapi melauli cerita orang tuapun seseorang mampu memahami keberadaan mejan tersebut. 


\section{Penyebab Pergeseran Pemahaman Masyarakat Terhadap Situs Purbakala}

Kebudayaan megalitik erat kaitannya dengan konsep-konsep religi masa lampau tentang kematian. Kematian sebagai ahir dari pejalanan hidup setiap manusia. Hingga sampai kini belum mampu menjelaskan dengan penalaran yang logis bagaimanaa kelangsungan sesudaah kematian. Namun sudah sejak dahulu kala manusia telah memiliki konsep-konsep religi tentang kelangsungan hidup sesudah kematian.

Menurut Koenjdaraningrat (1985:237) dalam laporan penelitian arkeologi (2003: 34) di dalam banyak konsep religi suku-suku bangsa di Indonesia, kematian menunjukkan adanya kepercayaan bahwa seeorang yang sudah tidak hidup lagi, akan menjadi mahluk halus. Mahluk halus diungkapkan seolah-olah memiliki keperibadian sendiri karena jiwanya tetah berubah menjadi ruh. Kepercayaan manusia akan adanya ruh yang dapat mempengaruhi kehidupan manusia bermula dari kepercayaan akan adanya kekuatan-kekuatan tertentu yang ada disekitar tempat tinggalnya, seperti batu besar maupunn pohon besar. Kepercayaan terhadap batu yang mempunyai pengaruh tertentu terhadap manusia hingga saat ini masih belangsung di beberapa daerah di Indonesia.

Situs purbakala seperti mejan umumnya berguna sebagai media penghubung kepada arwah nenek moyang. Seperti halnya orang pakpak dahulu yang masih menaganut paham animism atau sipelebegu mereka percaya bahwa arwah nenek moyang mereka dapat memberikan berkah apabila senantiasa menjalin komunikasi dengan leluhur mereka itu yang sudah berada di dunia mereka yang baru. Maka mejan tidak jarang diperlukan sebagai media komunikasi tersebut.

Akan tetapi hal yang telah dijelaskan di atas merupakan pandangan masyarakat Pakpak terdahulu sebelum masyarakatnya mengenal agama. Berbeda dengan pandangan masyarakat saat ini khususnya di desa Mahala. Saat ini masyarakat sudah meninggalkan ritual-ritual yang berhubungan dengan mejan. Beberapa alasan di bawah ini mengapa terjadi pergeseran pemahaman masyarakatnya terhadap situs purbakala

\section{Masyarakat Sudah Memiliki Agama Resmi}

Agama merupakan prinsip atau sebuah kepercayaan kepada Tuhan. Jika seseorang tidak memiliki iman atau kepercayaan yang kuat maka dapat dikatakan bahwa orang tersebut telah melanggar norma atau hukum agama. Setiap agama mengharuskan umatnya untuk berbakti dan melakukan kewajibannya, jika hal-hal terssebut dilanggar, makaa hukum agama akan menjadi dasar dalam pemecahan persoalan tersebut. Setiap agama memiliki aturan yang berbeda-beda yang telah tercantum pada 
kitab suci agama masing-masing, namun secara umum kebaktian dan ketaatan adalah hal yang selalu diajarkan. Seperti halnya yang dijelaskan oleh salah seorang informan Aman Boang Menalu (32) Tahun pada tanggal 30 April 2017:

"saat ini mejan sudah tidak diperlakukan lagi seperti dahulu, karena masyarakat disini sudah memiliki agama/keyakinan masing-masing. Bukan seperti para orang tua terdahulu yang belum mengenal agama. Sehingga mejan dianggap sebagai pelindung mereka. Akan tetapi walaupun masyarakat disini tidak memperlakukan mejan seperti orang tua dahulu, bukan berarti kami meninggalkan dan merusak mejan. Tidak! kami tetap menjaga dan melindunginya dari pencurian. Karena mejan memiliki nilai dan harga yang sangat fantastis di pasar gelap sehingga bayak orang laur yang menginginkan mejan. Dan juga mejan adalah peninggalan sejarah yang luar biasa bagi kami”.

Dari penjelasan informan di atas masyarakat Desa Mahala tidak merusak dan membiarkan mejan begitu saja, mejan masih tetap di jaga dan dilindungi karena bagi masyarakat mejan adalah peninggalan nenek moyang yang memiliki nilai sejarah yang luar biasa. Bukan hanya keturunan pertaki yang menjaga mejan tersebut akan tetapi masyarakat setempat dan pemerintah pun ikut berpartisispasi dalam pelesterian benda cagar budaya tersebut.

\section{Masyarakat Sudah Mengenal Hukum}

Hukum adalah aturan, apabila dilanggar akan mendapatkan sanksi. Masyarakat desa mahala saat ini sudah mengenal hukum, baik itu hukum adat, hukum Negara, dan hukum agama. Sehingga kepercayaan dan pemujaan terhadap mejan oleh orang-orang dahulu, sudah tidak dilakukan lagi saat ini. Seperti yang diterangkan oleh seorang informan Sariah Solin (63) Tahun pada tanggal 1 Mei 2017.

"dahulu mejan dipercayai sebagai pelindung, karena mejan dapat memberi tanda dan mengelurkan suara apabila desa akan terkena musibah atau kedatana orang jahat. sehingga orang-orang dahulu sangat menuruti segala permintaan ruh yang tinggal di mejan tersebut. Apapun permintaan yang yang disampaikkan ruh melalui dukun ataupun keturunan pemilik mejan, akan ddisediakan oleh orang-orang dahulu. Karena mereka takut ruh yang tinggal dimejan marah dan murka. Orang-orang yang melanggar atau tidak memenuhi permintaan akan mendapatkan bala sebagai ganjarannya. Sehingga orang-orang dahulu patuh kepada mejan. Hari ini hal itu bukan ancaman lagi, karena masyarakat sudah mengenal dan patuh terhadap hokum yang berlaku di 
masyarakat sepertik hukum adat, hokum pemerikntah ddan hokum agama"

Jelas sekali pendapat yang di paparkan oleh Sariyah Solin di atas bahwa masyarakat telah mengenal hukum yang berlaku di masyarakat, di Negara, dan agama. Hanya hukum, adat, Negara dan agama yang patut untuk dipatuhi oleh masyarakat. Selain masyarakat sudah menganut kepercayaan/agama masing-masing dan masyarakatnya juga telah mengenal hukum, ada beberapa informan dengan pendapat dan penjesan yang sama, yaitu hal-hal yang menyebabkan terjadinya pergeseran pemahaman masyarakat desa mahala didasari oleh kemajuan jaman yang semakin canggih.

\section{Zaman Semakin Modern}

Semakin canggihnya jaman, semakin maju pulalah pengetahuan masyarakat. Sudah bnyak masyarakat yang pintar mengikuti perkembangan teknologi dan kemajuan dunia. Sudah memadainya sarana teknologi dan informasi yang digunakan oleh masyarakat saat ini, misalya televisi, hanphone genggam, komputer yang sudah difasilitasi oleh tenaga wifi dari kantor kepala desa, dan lain sebaginya. Sehingga pemahaman masyarakat saat ini khususnya didesa Mahala tentang situs purbakala seperti mejan ini lambat laun semakin terlupakan. Banyaknya masyarakat yang tidak membutuhkan lagi pengaruh mejan saat ini ada kehidupannya beda dngan masyarakat dahulu yang selalu mengikutsertakan mejan dalam hal apapun itu. Seperti yang dijelaskan oleh salah satu dari beberapa informan lainnya, yaitu Aman Boang Manalu (32) Tahun pada tanggal 30 April 2017:

"mejan saat ini sudah mulai terlupakan, terkhususnya pada generasi muda sekarang ini. Ada anak muda yang bahkan tidak mengerti lagi apa itu mejan, mungkin juga karena faktor lamanya merantau di kota orang. Kemudian setelah masyarakat dikenalkan oleh teknologi informasi dengan berbagai kegunaan, penyebab salah satu pergeseran untuk memahami situs purbakala seperti mejan ini. Bagi saya ssetelah dunia semakin maju dan penuh dengan pengetahuan seperti saat ini, mejan hanya menjadi kenang-kenangan yang dibuat nenek moyang untuk mengingat mereka. lya, hanya kenag-kenangan bagi saya"

Mejan saat ini hanya sebatas kenang-kenangan bagi sebagian masyarakat, akibat kemajuan dan pengetahuan yang sudah dimiliki oleh setiap orang di Desa Mahala. Sehingga pengetahuan mengenai mejan mulai pudar. Sebenarnya dalam hal ini terjadi kesalahan yang dilakukan oleh oknum yang tidak bertanggung jawab. Seperti yang diterangkan oleh Nurli Berutu (67) Tahun pada tanggal 4 Mei 2017. 
"kalo uang yang diberikan oleh pemerintah tahun lalu betul-betul digunakan untuk membangunan dan memagari mejan itu, mungkin banyak orang yang akan berkunjung dan melihat situs purbakala itu, sehingga bayak para generasi muda sekarang ini mulai menanyakan kemabali arti mejan bagi kehidupan orang-orang dahulu. Sehingga mejan ini akan lebih terawatt dan lebih terlestarikan kembali. Dana yang sudah diberikan sbesar 20 juta menurut cerita orang-orang tidak tahu kemana arahnya, dan hingga saat ini tidak ada yang mengetahuinya"

Benar seperti yang telah diterangkan oleh ibuk Nurli Bancin. Apabila dana yang dikelurakan dari pusat digunakan betul-betul untuk pembangunan dan pemagaran situs purbakala ini maka akan banyak generasi-generasi muda, orang-orang desa yang sebelumnya belum pernah melihat langsung mejan seperti apa, masyarakat perantau, bahkan masyarakat luarpun akan tertarik untuk melihat dan mengunjungi mejan tersebut, walaupun tidak memaknai mejan sama seperti pemaknaan bagi orang-orang dahulu setidaknya masyartakat paham bahwa mejan tetap menjadi situs purbalaka yang memiliki sejarah yang luar biasa.

Dari beberapa informan yang peneliti temui, ada berbagai pendapat dan pemahaman yang berbeda-beda dan adapula pendapat yang sama. Menurut peneliti itu semua kembali pada pemikiran masing-masing masyarakat dalam memahami penyebab pergeseran pemahaman msyarakat terhadap situs purbakala ini. Namun, pada dasarnya masyarakat melihat mejan ini sama, walaupun sebagaian masyarakat menganggap mejan hanya sebatas peninggalan nenek moyang sebagai kenang-kenangan semata, namun masyarakat tidak memungkiri bahwa mejan ini umumnya dijadikan sebagai simbol kemansyuran masyarakat dahulu .

Pemahaman mengenai mejan pada masyarakat Pakpak Desa Mahala saat ini sangat jauh berbeda dengan masyarakat Desa Mahala dahulu. Apabila masyarakat dahulu memaknai mejan sebagai simbol kemansyuran dan benteng pertahanan, beda halnya dengan saat sekarang ini dimana mayarakat menganggap mejan hanyalah peninggalan nenek moyang sebagai kenang-kenangan semata.

\section{Penutup}

Artikel ini memperlihatkan mengenai perubahan pemahaman masyarakat saat ini tentang keberadaan situs purbakala seperti mejan, maka penulis mengambil beberapa kesimpulan bahwa, saat ini masyarakat Pakpak khususnya masyarakat di Desa Mahala menyebut mejan sebagai harta pusaka peninggalan nenek moyang pemilik marga tertentu yang memeiliki 
nilai yang sangat berharga, dikarenakan tidak semua marga atau orang yang mampu membangun mejan tersebut. Hanya orang kaya yang memeiliki kekusasaan yang mampu membangun mejannya. Dahulu mejan difungsikan sebagai lambang kemansyuran atau kebesaran seorang raja pemilik marga. Selain dijadikan sebagai lambang, mejan juga diyakini sebagai benteng pertahanan karena memiliki kekuatan untuk menangkal bala dan serangan dari musuh. Mejan juga di anggap sebagai simbol kepahlawanan, karena mejan merupakan salah satu wujud penghargaan kepada seseorang yang dianggap berpengaruh atau berjasa kepada masyarakat. Selain itu mejan juga diyakini sebagai tanda hak ulayat atas tanah seorang raja. Namun saat ini, seiring berjalannya waktu dan kemajuan zaman fungsi mejan mulai berubah, mejan hanya menjadi benda-benda peninggalan yang bersejarah bagi masyarakat. Beda halnya dengan pandangan masyarakat luar saat ini, dari kasus pencurian mejan yang pernah terjadi di beberapa tempat di Pakpak Bharat mengisaratkan bahwa mejan memiliki harga jual yang tinggi. Untuk lebih memahami keberadaan situs purbakala masyarakat harus melihat objeknya langsung, bukan hanya pemahaman dari mitos dari cerita-cerita rakyat, akan tetapi sebagian masyarakat juga menjelaskan kebalikan dari sebelumnya.

\section{Daftar Pustaka}

Berutu, Lister, Dkk. 2013. Sejarah Berdirinya Kabupaten Pakpak Bharat, Medan: Grasindo Monoratama

Bustanuddin, Agus. 2006. Agama Dalam Kehidupan Manusia: Pengantar Antropologi Agama, Jakarta: Raja Grafindo Persada

Daeng, Hans J. 2008. Manusia, Kebudayaan Dan Lingkungan, Yogyakarta: Pustaka Pelajar

Gultom, Ibrahim. 2010. Agama Malim Di Tanah Batak, Jakarta: Bumi Aksara

Koentjaraningrat. 1987. Sejarah Antropologi I. Jakarta : Penerbit Universitas Indonesia

2002. Pengantar IImu Antropologi. Jakarta : PT Renika Cipta

Maibang, Ringgas 2009. Mengenal Ethnis Pakpak Lebih Dekat. Medan : tanpa penerbit

Makmur, Mariana, Dkk. 2002. Aspek-Aspek Kultural Etnis Pakpak Suatu Eksplorasi Tentang Potensi Lokal. Medan : Monora

Maryaeni. 2008. Metode Penelitian Kebudayaan. Jakarta : PT Bumi Aksara Moleong, Lexy J. 2004. Metodologi Penelitian Kualitatif. Bandung: PT Remaja Rosdakarya

Pals L, Daniel. 2012. Seven Theories Of Religion. Jogjakarta: IRCiSoD

Sanafiah,Faisal. 1999. Metode Penelitian Kualitatif Dan Kuantitatif. Jakarta : Raja Grafindo Persada 
Saifuddin, Achmad Fedyani. 2005. Antropologi Kontemporer Suatu Pengantar Krisis Mengenai Paradigma. Jakarta: Kencana

Spradley, James P. 2006. Metode ethografi. Yogyakarta: Tiara Wacana

Wahyudhi. 2002. Ethnis Pakpak Dalam Fenomena Pemekaran Wilayah Mempertanyakan Partisipasi Politik Perempuan Dalam Masyarakat.

Sidikalang : The Asia Foundation \& Yayasan Sada Ahmo

Jurnal Dan Skripsi

Skripsi. Saut banuera. 2014. Analisis bentuk dan fungsi patung mejan pada suku pakpak di kabupaten pakpak bharat.

http://ejournal.unicen.ac.id/index.php/JIS/article/download/263/244 http://text.123dok.com/document/1990-fungsi-patung-ojizo-dalam-

masyarakat-jepang.htm

http://text.123dok.com/document/43168-pandangan-masyarakat-okinawaterhadap-patung-shisa.htm

perencanaan/rpjmd/item/download/16_d71ef937849b8b75b2750d593f570c 95 